\title{
Development of Microclimate Regulatory Clothe
}

\author{
I. SAHTA ${ }^{1}$, Mg. sc. ing., I. BALTINA ${ }^{2}$, Dr. sc. ing., J. BLUMS ${ }^{3}$, Dr. phys \\ ${ }^{1-2}$ Riga Technical University, Institute of Textile Material Technologies and Design, LV \\ ${ }^{3}$ Riga Technical University, Institute of Technical Physics, Latvia
}

\section{Summary}

To avoid adverse environmental temperature effects on human body and working capacity, it is possible to manufacture the garments with integrated electrical systems and such components as Peltier elements, able to provide the microclimate regulatory function. Such clothe have to ensure not only effective operation of the system, but also the clothing requirements, such as comfort, light weight, air permeability, etc.

The research is dedicated to microclimate regulatory vest with an integrated electrical system, which is also composed Peltier elements, and cooling function is based on the heat conductivity in solids. For development the system and the clothe it is performed experiments to optimize the product microclimate regulatory function.

\section{Introduction}

As one of the human microclimate regulatory solutions, could be mentioned the garment with integrated Peltier elements. [1]

In the world is already discovered and patented smart clothes and other articles, with integrated thermoelectric converters. Here should be mentioned articles with several thermoelectric modules [2]; with integrated heat exchanger with piping system [3] and with air conditioners [4]. Systems differ in terms of power source selection; both of the solution the heat removal from Thermoelectrical module cold side, but also of the cooling type the warm side.

\section{Concept of microclimate regulatory clothes}

One of solutions to this area is the prototype - the vest with integrated Peltier elements, developed in Riga Technical University (see Fig.1.), where the microclimate regulation is based on the heat transfer in solids.

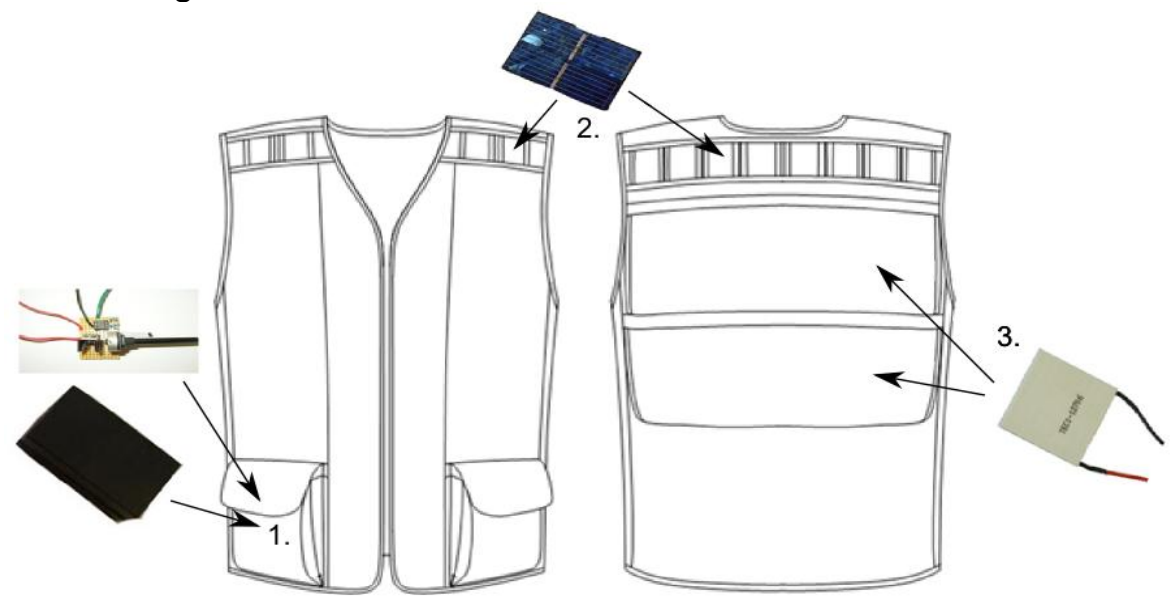

Fig. 1. Overview of microclimate regulatory vest prototype 
There is shown in Figure 1.: 1 - power source, battery and control system, 2 solar cells, 3 - Peltier elements.

Incorporation of Peltier element: for each element in the garment there is designed "box". The heat, created by the current, is absorbed by the copper radiator, attached to hot surface of the element (Fig. 2). The knitted metal material, attached to the surface of the element, is used to increase cooling surfaces and for the smooth the temperature conduction (Fig. 3). Four Peltier coolers are placed on in the field of shovels on a back.

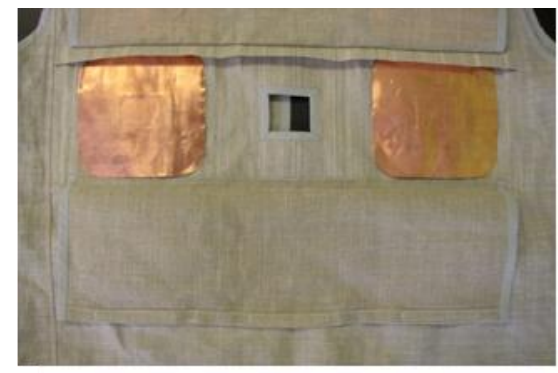

Fig. 2. Copper radiator on the hot surface

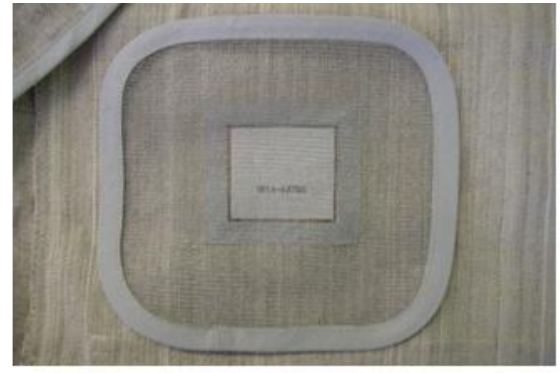

Fig. 3. The knitted metal material on the cold surface of element

Several experiments have demonstrated the possibility of system operation.

To verify microclimate regulatory vests compliance with the general requirements of article, it is scheduled an assessment at physiologically hygienic point of wearing by the appropriate operating conditions, during exercise by measuring temperature changes in different locations in space between the body and clothes.

\section{Conclusions}

1. Experimentally it is proven operation of cooling system

2. Copper foil provides the necessary heat removal, in both $3 \mathrm{~cm}$ and $6 \mathrm{~cm}$ distance from the Peltier element cooling surface

3. The copper foil have to be replaced by a material, which wouldn't limit clothing requirements and functions

4. The problem area: integration of system in smart clothes

\section{References}

[1] 1.Bansevičius R, Račkiene R, Virbalis J. A.. The body Cooling System Integrated into the Clothes//Electronics and electrical engineering. - 2007. - No. 5 (77). - S. 3-6

[2] United States Patent No: US 6,739,138 B2, Thermoelectric modules and a heating and cooling apparatus incorporating same. J. Saunders, J. D. Jacob, D. Gao, M. A. Myers. Reǵ. - 02.07.2002 10/186,618, publikācija: US 2003/0097845 29.05.2003, Int. Cl. F25B 21/02

[3] United States Patent No: US 7,186,957 B2, Temperature regulated clothing. R. Martin. Reǵ. - 06.08.2003 10/636,511, publikācija: US 2004/0118831 A1 24.06.2004, Int. Cl. H05B 3/34

[4] United States Patent No: US 6,823,678 B1, Air conditioner for flexible materialbased devices. Li Zhixinn. Reǵ. - 22.12.2003 10/743,640, publikācija: 30.11.2004, Int. Cl. F25B 21/02 